\title{
Service Quality, Tax Awareness and Tax Fairness as Determinants of Tax Compliance among E-Commerce Enterprises in Malaysia
}

Izzie Hadzree Khamis, Nor Hamimah Mastor

To Link this Article: http://dx.doi.org/10.6007/IJARBSS/v11-i2/9190

Received: 14 December 2020, Revised: 16 January 2021, Accepted: 27 January 2021

Published Online: 19 February 2021

In-Text Citation: (Khamis \& Mastor, 2021)

To Cite this Article: Khamis, I. H., \& Mastor, N. H. (2021). Service Quality, Tax Awareness and Tax Fairness as Determinants of Tax Compliance among E-Commerce Enterprises in Malaysia. International Journal of Academic Research in Business and Social Sciencess, 11(2), 938-951.

Copyright: (C) 2021 The Author(s)

Published by Human Resource Management Academic Research Society (www.hrmars.com)

This article is published under the Creative Commons Attribution (CC BY 4.0) license. Anyone may reproduce, distribute, translate and create derivative works of this article (for both commercial and non-commercial purposes), subject to full attribution to the original publication and authors. The full terms of this license may be seen at: http://creativecommons.org/licences/by/4.0/legalcode

Vol. 11, No. 2, 2021, Pg. 938 - 951

Full Terms \& Conditions of access and use can be found at http://hrmars.com/index.php/pages/detail/publication-ethics 


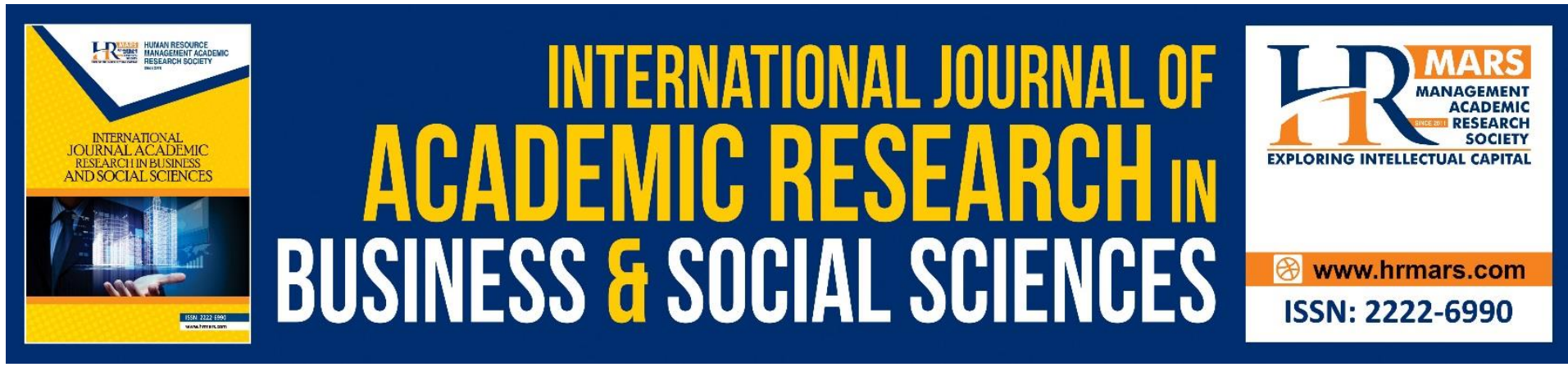

\title{
Service Quality, Tax Awareness and Tax Fairness as Determinants of Tax Compliance among E- Commerce Enterprises in Malaysia
}

\author{
Izzie Hadzree Khamis, Nor Hamimah Mastor \\ Azman Hashim International Business School (AHIBS), Universiti Teknologi Malaysia (UTM) \\ Malaysia
}

\begin{abstract}
Nowadays, e-commerce has become a dynamic part of our daily basis. E-Commerce is a platform to sell goods and services online and allows business transactions to be carried out without limit of marketplace. These scenario has attracted major concern among international agencies and tax authorities over the world particularly on the issue of its taxable income. Taxation of e-commerce is a major concern for international agencies and tax authorities over the world. The issue such as tax non-compliance including tax evasion and tax avoidance is very crucial. Thus, this article is an early study proposing a research model to examine the determinants of tax non-compliance among e-commerce enterprises in Malaysia. This is due to the lack of previous studies about tax non-compliance in e-commerce perspective. A content analysis method was utilized to identify the relevant precursors of tax compliance among e-commerce enterprises owners. This paper will discuss three factors of tax compliance namely service quality, tax awareness and tax fairness.
\end{abstract}

Keywords: E-Commerce Taxation, Tax Compliance, Service Quality, Tax Awareness, Tax Fairness.

\section{Introduction}

The rapid growth of the electronic commerce which implies the sale of goods and services using the facilities provided by the internet has raised various issues including including taxation particularly in dealing with tax collection and its taxable income status.

In the context of Malaysia business, e-commerce businesses were shown to be in a consistent growth and predicted with positive growth onwards. Malaysia Investment Development Authority (MIDA) (2019) reported that the e-commerce industry has grown into one of Malaysia's most significant and competitive industries in the past 12 months. This statement was supported by survey from Department of Statistic Malaysia (DoSM). According to Department of Statistics Malaysia, (2020), the income from e-commerce transactions between 2015 and 2017 grew by 6\% annually with an almost RM50 billion increase in revenue. While data from German online statistics portal Statista shows the Malaysian ecommerce market for 2019 generated a revenue of US\$3.68 billion (RM15.2 billion), with a prediction for annual market growth to reach $11.8 \%$ by 2023 . Based on latest survey finding by DoSM on July 2020, households who spend on goods and services via e-Commerce rose 
from $11.3 \%$ on 2016 to $23.3 \%$ percent on 2019 . Distribution by state shows households in Selangor recorded the highest percentage of using e-commerce which is $27.8 \%$, followed by Johor (12.3\%), Pulau Pinang (9.2\%), Perak (8.9\%) and W.P. Kuala Lumpur (8.1\%).

Moreover, this current trend was due to the pandemic situation, whereby both individuals and companies, shifted their interest in e-commerce as they realized the many benefits they can enjoy. E-commerce has increased whereby the buyers in developed countries even in developing countries such as Malaysia, Singapore, Thailand, and Pakistan (Akram \& Khan, 2020).

Nevertheless, although e-commerce businesses were mushrooming, tax on e-commerce is understudied by the whole world. In fact, many products or services transacted online to go untaxed.

\section{Background of the Study}

One prominent problem among e-commerce practitioners is that they tend to evade taxation when they do business online or by phone. They assume that tax authorities will not be able to detect their online business income (Hamid et al., 2019). This is because e-commerce business conducted over the Internet is completely different from other practices of businesses. The e-commerce is described as being borderless since its transactions have been observed to flow flawlessly across international borders. Therefore, the taxation of these borderless transactions seems very unfeasible (Turban et al., 2018). Moreover, no evidence of transaction in e-commerce business coupled with no compulsory order to prepare an audited account enhance the likelihood of undetectable transactions. The Internet does not leave any paths that can help the relevant tax authorities to track e-commerce players' locations and thus the taxation becomes a loopholes. Millions of tax revenue were lost as the e-commerce penetrators continue to dig deeper into the governments' jurisdictions as to confirm the relevant authorities find it impossible to control this issue (Mohammad, 2019).

Yapar et al (2015) claimed that because of the implication of uncertainty territory and jurisdiction elements of e-commerce taxation could greatly effected tax collection and tax loss. Based on the "Guideline on Taxation of Electronic Commerce Transaction" by Inland Revenue Board of Malaysia (IRBM) (2013), e-commerce is defined as any commercial transactions conducted through electronic networks including the supply of data, promotion, marketing, supply, order or delivery of products and services through payment and delivery concerning such transaction could also be conducted off-line (IRBM, 2013). Initially, the IRBM adopts the principles of neutrality where both e-commerce and conventional business was subject to the same tax treatment. However, in 2016 there was outbreak of polemic among e-commerce merchants regarding the online business taxissues. The Inland Revenue Board Malaysia (IRBM) has issued a press release dated 23 May 2016 for explaining the specific provisions applicable to the e-commerce service and business taxation treatment in Malaysia but e-commerce enterprise taxpayer still not aware with their obligation to report the e-commerce business income. The Malaysian Reserve online dated 14 September 2017, reported that the IRBM claimed that many e-commerce practitioners think they can evade taxation simply because they conduct businesses online. Therefore, the Inland Revenue Board is keeping a close tab on online commercial activities.

Tax avoidance and inevitably evasion are involved concerns about tax compliance among e-commerce (Westberg, 2002). In an e-commerce business, the possibilities of hiding transactions are huge and the possibilities contribute to a transaction are in many cases virtually non-existent. Tax non-compliance including tax avoidance and tax evasion has 
always been problems with which tax authorities have had to combat. Although the development of information technology (IT) and the Internet has greatly expanded business opportunities, it also contributes to illegal activities online, and create a new category of entrepreneurs who operate outside law or at the boundaries of the law (Dobson et al., 2015) which, in turn, leads to wide scopes of the digital shadow economy. On $16^{\text {th }}$ October 2019, New Straits Times reported Finance Minister said Malaysia's shadow economy - which comprises illicit activities such as black market transactions and undeclared work - is worth about RM300 billion (US\$73.8 billion) or 21 per cent of the country's gross domestic product (GDP). He added that the government had to expand its revenue based and reduce tax gaps to ensure sustainable collection for the Malaysia development. Due to that, The Malaysian Reserve Online dated $7^{\text {th }}$ November 2019 reported that IRBM CEO Datuk Seri Dr Sabin Samitah said $20 \%$ of its total current workforce will be absorbed which make it $80 \%$ of total officers to do enforcement into tapping income tax revenue from the shadow economy. This shown that there are a lot of challenges faced in tackling the shadow economy which intuitive from e-commerce business. Many complex and disruptive forces are involve. The rapid globalization, fast evolving business environment shaped by the deployment of digitalized technology as well as the rise of e-commerce and sharing economy would have make it more complex for the tax authorities to track, measure and control it (The Star Online, 2020).

\section{Problem Statement}

The abovementioned reasons have called for this current study, particularly to understand the tax compliance among e-commerce environment and give inputs to tax authority in order to educate and create awareness among e-commerce business owner. A number of public rulings have been issued by the IRMB since the Self-Assessment System (SAS) basically to educate and to provide guideline for public to self-calculate their tax. Tax education is part of the service provided by the authority including spreading the information, understanding and guidance to the public especially taxpayers about taxation and tax law. Generally, business owners who understand tax regulations would adhere the regulations to prove that they practiced good conduct of business and minimizes the risk of regulatory fines.

Service quality, on the other hand, enhances business owners' confidence and satisfaction which is closely related to tax compliance. In addition, service quality were empirically function as an important role to influence satisfaction, profitability, customer loyalty and repurchase behavior. Thus, it is expected to influence tax compliance as well. Finally, perception of tax fairness create ethical attitudes which eventually improve decision of moral and choices and induce tax compliance.

Based on the enlightenment, e-commerce enterprises compliance has a great role in economic impact of the government and should be improved to create an obedience culture. Therefore, recognizing the significant effects of tax compliance among e-commerce enterprises in Malaysia, the purpose of this paper is to determine factors of tax compliance in e-commerce environment namely service quality, tax awareness and tax fairness. The identification of these factors will give useful insights to the tax authorities particularly in improving future tax policies in the field of e-commerce taxation and subsequently for the better compliance enforcement. 


\section{Research Questions}

Based on relevant issues, the research question of the e-commerce study were arise to be answered such as below:

1) Does the tax service quality contribute to the tax compliance among e-commerce enterprises in Malaysia?

2) Does the tax awareness contribute to the tax compliance among e- commerce enterprises in Malaysia?

3) Does the perception of tax fairness contribute to the tax compliance among ecommerce enterprises in Malaysia?

\section{Research Objectives}

To accomplish the above research questions, the specific research objectives of this study were as follows:

1) To examine the association between service quality factor and tax compliance among e- commerce enterprises in Malaysia.

2) To examine the association between tax awareness factor and tax compliance among e- commerce enterprises in Malaysia.

3) To examine the association between tax fairness factor and tax compliance among ecommerce enterprises in Malaysia.

\section{Literature Review \\ Tax Compliance}

There are various and no standard definition of tax compliance. The two type of tax compliance are administrative compliance and technical compliance (OECD, 2001). Administrative compliance involves complying with the administrative rules of declare tax returns and paying tax on time, while technical compliance relates to the calculation and payment of taxes based on the technical requirements of the provisions of the tax laws. The three aspects of tax compliance consist of filing, reporting and payment. Franzoni (2000) stated compliance as to report true tax base, to calculate tax liability correctly and to file tax returns in a timely and appropriate manner. Any contrary behavior of the above are considered as non-compliance.

Tax compliance can also be regarded as the degree to which taxpayers comply with the tax laws (James \& Alley, 2009). James and Alley further emphasized that compliance refers to voluntary behaviour. Hence, they defined tax compliance as the degree of compliance with tax laws and administration without the request of any enforcement activity. Widely defined, tax non-compliance consist both tax avoidance and tax evasion (James \& Alley, 2009). Their different criteria lies in its legality. Tax avoidance involves eliminating or minimizing the tax liability within the scope of the law. Oppositely, tax evasion involves an effort to minimize or totally eliminate the tax liability by illegally means by breach the tax laws (Singh, 2005) . As such, while tax avoidance is legal, tax evasion is not. However, both involve manipulation of a person's activities to reduce tax liability, but tax avoidance employed legal measures whereas tax evasion used illegal measures.

Tax avoidance is commonly practiced using intelligent analysis and choice of alternatives with less tax impact and by taking advantage of faults and loopholes in the existing tax laws (Singh, 2005). It contains effective use of both the legitimate fiscal policies and technical lacks and ambiguity in the tax laws, which results in either permanent elimination of tax liability or a postponement of it (Singh, 2005). Common tax avoidance tactically include various tax 
planning strategies such as utilizing various tax deductions and exemptions, managing capital expenditure to get maximum capital allowance, structuring a transaction to switch income receipt arises as capital and transfer pricing not in an arm's length arrangement (Singh, 2005). Meanwhile, tax evasion is characterized by a deception and willful mind aims at paying less tax than it is legally due through unlawful courses of action.

Tax evasion includes failure to disclose income or non-filing of tax return, failure to file return on time, or intentionally improper filing; illegally reducing tax by underreporting income or over reporting deductions by making false declarations or use fake invoices, making false claims to allowances and failure to pay tax by the due date (Kirchler et al., 2003). Although, the conceptual difference between tax avoidance and tax evasion depends on the legality of the taxpayer's actions (Sandmo, 2005) the intention of both tax evasion and tax avoidance is the same, that is to escape tax and the effects are similar which is to make private gains at the expense of public loss (McBarnet, 2017), and results in loss of revenues to the government (Singh, 2005).

\section{Service Quality}

Service quality has been defined by some researchers, but one of the most commonly accepted definition is the difference between expectation and actual performance (Parasuraman et al., 1985). The service quality also can be defined as a degree of excellent either objectively or subjectively, evaluated. It is a judgment of how well a distributed service adapts to the customer's expectation. Service business providers frequently assess the service quality provided to their customer to increase their service quality, identify problems and to attain customer satisfaction (Stiglingh, 2014).

In the context of taxation, Ott (1998) indicated that the quality of tax service was considered as evidence that the society was modern and shown that the tax authority will always provide better service to taxpayers. On the other hand, Savitri and Musfialdy (2016) interpreted the service tax as a way to help tax officials, administer, or prepare all the requirement purposes for taxpayers. They also clarified that taxpayer had to be treated in a similar way like in other private businesses.

Quality of tax service is measured by whether taxpayer satisfied or not satisfied. Service which up to the standard can provide satisfaction to taxpayers and can be accounted for and must be carried out consistently. Parasuraman et al., (1985) stated that the quality of service is determined by five factors, which are tangibles, reliability, responsiveness, assurance and empathy. Tangibles consist of physical facilities, equipment, and staff appearance. Reliability means ability to perform the promised service dependably and accurately whereby responsiveness is willingness to help customers and provide prompt service. Assurance defined as knowledge and courtesy of employees and their ability to inspire trust and confidence while empathy is caring and individual attention the firm provides its customers. These dimensions primarily focus on the human aspects of service delivery (responsiveness, reliability, assurance, and empathy) and the tangibles of service.

Thornton and Shaub (2014) categorized the tax service provided by tax authority into three categories, which are information, interaction and transaction. The transaction is the interior service, whereby information and interaction services are complementing the transaction service. The previous study by Mustapha and Obid (2015), measure the tax service quality by three component factors such as responsiveness, reliability and informativeness.

Responsiveness is aimed at how fast are the administrators will respond to any inquiries made by the taxpayers. The responsiveness refers to the availability to attend taxpayers in accurate 
and timely manner. Moreover, it also indicate how friendly the system in terms of format when they need to update the taxpayer's particular such as status, location and mode of payment of their tax. Liljander et al., (2006) examined the quality of dimension of responsiveness in terms of the response to feedback. It is consistent with Parasuraman et al., (1985) research that emphasized on responsiveness which deserves more attention with respect to tax quality.

Reliability is the process which the system has the capacity to access it's administration task accurately and dependably by evaluating as demand (Miazee \& Rahman, 2011). The finding of Miazee and Rahman (2011) is similar with the view of Parasuraman et al., (1985) that listed reliability as the most significant measurement in all service's quality dimensions. Reliability in tax service quality is important because when evaluating an innovation, there is a need to know how reliable the system to meet the purpose of its adoption.

Informativeness in service quality refers to the quality of information provided and available on the online system or website presented by the tax authority (Barrios, 2010). The accuracy and completeness of the information could be improved with very objective measurement of information. Thus, the capability of tax authority to provide sufficient and helpful information will benefit tax administrators in return. The tax system which is more accurate, relevant and convenient to use are more effective when the information provided is in the interest of the taxpayer (Negash et al., 2003).

\section{Tax Awareness}

Tax awareness refers to taxpayers' understanding and consciousness of tax laws and regulations on the specific tax issues. Consciousness is an element in human beings to understand the reality and how they react towards the reality (Alabede et al., 2011). Savitri and Musfialdy (2016) describe that some form of consciousness of paying taxes will encourage taxpayers to pay tax, knowing and understanding about taxes. Based on this statement, it revealed that the taxation awareness is related to the taxpayers in paying their tax obligations, reporting tax Return, function and regulation along with the sanctions of the tax itself. Taxpayer awareness is understandable if the taxation regulation has been known, acknowledged, respected and followed. If the tax regulation is still not comply, that shows taxpayer's awareness is still low. The low awareness of taxpayer is suspected to be caused by the minimum knowledge and understanding of tax regulations (Yayuk et al., 2017).

Knowledge recognition and obedience to relevant tax law and regulation leads to tax awareness (Adhiambo \& Theuri, 2019). Education and other mode of assistance to increase awareness may impact tax compliance or might not have any change. Tax awareness will arise through education and tax knowledge for mutual benefits of government and taxpayers in order to improve taxpayers view and implemented of tax law by authority.

Setyonugroho and Sardjono (2012) summaries some indicators of awareness in paying taxes. There are three main indicators of awareness related to the payment of taxes, which are: (1) the awareness that taxes are main source in supporting the country's development. By knowing this, the taxpayers are willing to pay taxes because they will affected indirectly (2) The awareness that the delay in payment of taxes and the tax loss can cause unfavorable financial condition to the country. Taxpayers are willing to pay taxes because they understand that the delay in payment of taxes and the decline of the tax collection will impact on the reduced financial resources that could lead to the delays in development of the country. (3) The awareness that taxes are set by law and can be enforced by the authority. The awareness of enforcement will mobilize the taxpayers to meet their tax obligations by paying tax. 
Based on the explanation above, awareness of paying taxes can be measured as a form of moral attitude which gives contribution in order to support the development of the country and attempts to comply with all the rules set by the authority.

\section{Tax Fairness}

Another factor that most taxpayer concern about is referring to the tax fairness. A conceptual framework for fairness considerations suggest differentiating three area of fairness, as in psychology: distributive justice, which refer to the exchange of resource, both benefits and cost. Procedural justice refer to the process of the resource distribution, and retributive justice, refer to the perceived relevance of agreements in the case of norm-breaking (Kirchler et al., 2008). Tax fairness also can be perceived in two dimensions: horizontal equity (taxpayer in same tax brackets should pay the same amount of tax) and vertical equity (taxes paid increase with the increase in tax base)(Goetz, 1978).

Wenzel (2002) defines three types of fairness: distributive fairness, procedural fairness, and retributive fairness. Distributive fairness focus on the fair distribution of costs and benefits in tax payment. Procedural fairness refers to equal tax collection among groups of taxpayers. While, fair treatment of taxpayers in the use of forced power in punishments and audits, is called retributive fairness.

In distributive fairness, an individual is concerned with the equality of the outcome and wants to be treated based on his or her merits, efforts, and needs (Kirchler et al., 2008). In procedural fairness, the main elements for perceived fairness are neutrality of procedures, trustworthiness of tax authorities, polite, distinguished and respectful treatment (Tyler \& Lind, 1992). Retributive fairness, on the other hand is unreasonable and disturbing audits, and unfair penalties will result a stressful and dissatisfied taxpayers (Wenzel, 2002).

Relationship between Tax Compliance and Service Quality, Tax Awareness and Tax Fairness. Relationship between Tax Compliance and Service Quality.

The quality of service which up to the standard can provide satisfaction to taxpayers and can be accounted for and must be carried out consistently. Hanousek and Palda (2004) stated that the willingness of taxpayers to pay tax is largely influenced by the quality of services provided by the government. Feeling of pleasure and satisfaction with the services provided by the authority can initiate motivation and compliance for taxpayer. This is consistent with research by Torgler (2013) which suggested that a tax authority could improve the compliance of taxpayers by establishing cooperation with taxpayers. Torgler (2013) argued that the tax authority had to consider itself as service institution and provide quality service and treat taxpayers as their partner. So, the optimistic perception of taxpayer towards tax service quality will lead to more compliance and vice versa.

Based on previous findings, the present study has proposed that the behavior of taxpayer would change according to their opinion and attitudes about the quality of the tax service. This study is an attempt to demonstrate the relationship between tax service quality and tax compliance among e-commerce enterprises in Malaysia. Thus, the proposed hypothesis is:

H1 : Service quality should have a significant positive relationship with tax compliance among e-commerce enterprises in Malaysia.

\section{Relationship between Tax Compliance and Tax Awareness}

There is a fact that tax is a source of revenue to support development of country. Knowing this reality, the taxpayer will pay tax because they know the important of it and if they delay 
to pay, it will give impact to lack of financial resources. The delay of resources may lead to domino effect in country's development. The realization that the tax is set of legislation and can be enforced, may encourage taxpayer to do their absolute duty to pay tax. The experiment conducted by the gurus of tax Eriksen,(1996) study the influence of tax awareness and taxpayer compliance. In the study, two group of bachelor's students are compared based on their assignment to study, which is on tax and marketing. The study found that student which study tax, reported to have more positive attitude towards tax compliance.

Youde and Lim (2019) in their study mentioned that taxpayer voluntarily pay taxes if they understand the variety of taxes that they have an obligation to pay and how to benefit from their contributions. While previous study from Kamil (2015) also found that taxpayer awareness has a strong, positive association with the tax compliance of individual taxpayers in seven region in Indonesia. This findings is similar to the study by Yee et al., (2017) which found that tax awareness has a positive association with tax morale statistically will increase tax compliance. Based on Palil and Rusyidi (2013) study, the concept of tax awareness refers to tax knowledge and tax education amongst taxpayers where tax knowledge improves individual's awareness and level of ethics towards tax compliance. Furthermore, understanding more about tax system will improve by tax education. Hastuti (2014) interpreted tax awareness as "self-awareness of taxpayers individually to take responsible to calculate, pay and report their own tax". Whereby Savitri and Musfialdy (2016), explained taxpayers awareness arise when taxpayers are knowledgeable of how to calculate tax and how to pay their tax liability. From previous research, tax awareness was defined through tax education and tax knowledge as dimensions. Multiple supporting literature review regarding tax awareness, hence developed the hypothesis as below:

H2 : Tax awareness should have a significant positive relationship with tax compliance among e-commerce enterprises in Malaysia.

\section{Relationship between Tax Compliance and Tax Fairness}

Taxpayer's perception on whether a tax system is fair and impartial is very important as previous studies in Richardson (2008), Murphy (2009) and Natrah (2012) successfully and proven that positive perception results in good compliance behaviors. If tax fairness perception found exists, voluntary compliance will increase and vice versa. Researchers such as Michael et al., (1993), Roberts \& Hite (1994), found that taxpayers are less compliant if they perceived unfairness in existing tax system.

There is condition which makes the competition unfair between corporate taxpayers and enterprises or individual taxpayers. For corporate taxpayers, audited account obligation has to be fulfilled, meanwhile no audited account obligation for enterprises business including ecommerce enterprises. Unfairness may also happened when government did not enforce tax rules to e-commerce taxpayer, while brick and mortar taxpayer have to pay taxes. This condition which some taxpayers have to pay taxes while some others don't, will lead directly to unfairness.

According to Smith (1976), taxation should be imposed according to equality, certainty, convenient and economy. Equality means tax will be charged to individual taxpayers or corporate taxpayer in fair and identical.

Perception of fairness can also create ethical attitudes among taxpayers, which involves moral issues that choices and deals with right and wrong behavior. There are also a range of related factor from cultural, organizational and external environment determine ethical behavior (Siahaan, 2005). The external factors that effect on ethical include political legal economic 
and international development (Siahaan, 2005). Tax fairness motivates to better and positive attitude toward tax. It summarized that tax fairness influence taxpayer ethical attitude.

Therefore, some researchers confirmed that fairness have significant correlation with tax compliance. A study in Malaysia found that procedural fairness has a positive impact on compliance behavior (Faizal \& Palil, 2015). In sum, if taxpayers perceived that the tax burden is fairly distributed with within a peer group, tax compliance will increase. This discussion leading to the following hypothesis:

H3 : Tax fairness should have a significant positive relationship with tax compliance among e-commerce enterprises in Malaysia.

\section{Conceptual Model}

Based on the abovementioned hypotheses development in the previous subsection, the research model is then shown in Figure 1 . The model proposes that compliance in ecommerce tax is influenced by service quality, tax awareness and perception of equity and fairness. This means that the greater the service quality, tax awareness and tax fairness, the higher the compliance among e-commerce enterprises in taxation and vice versa.

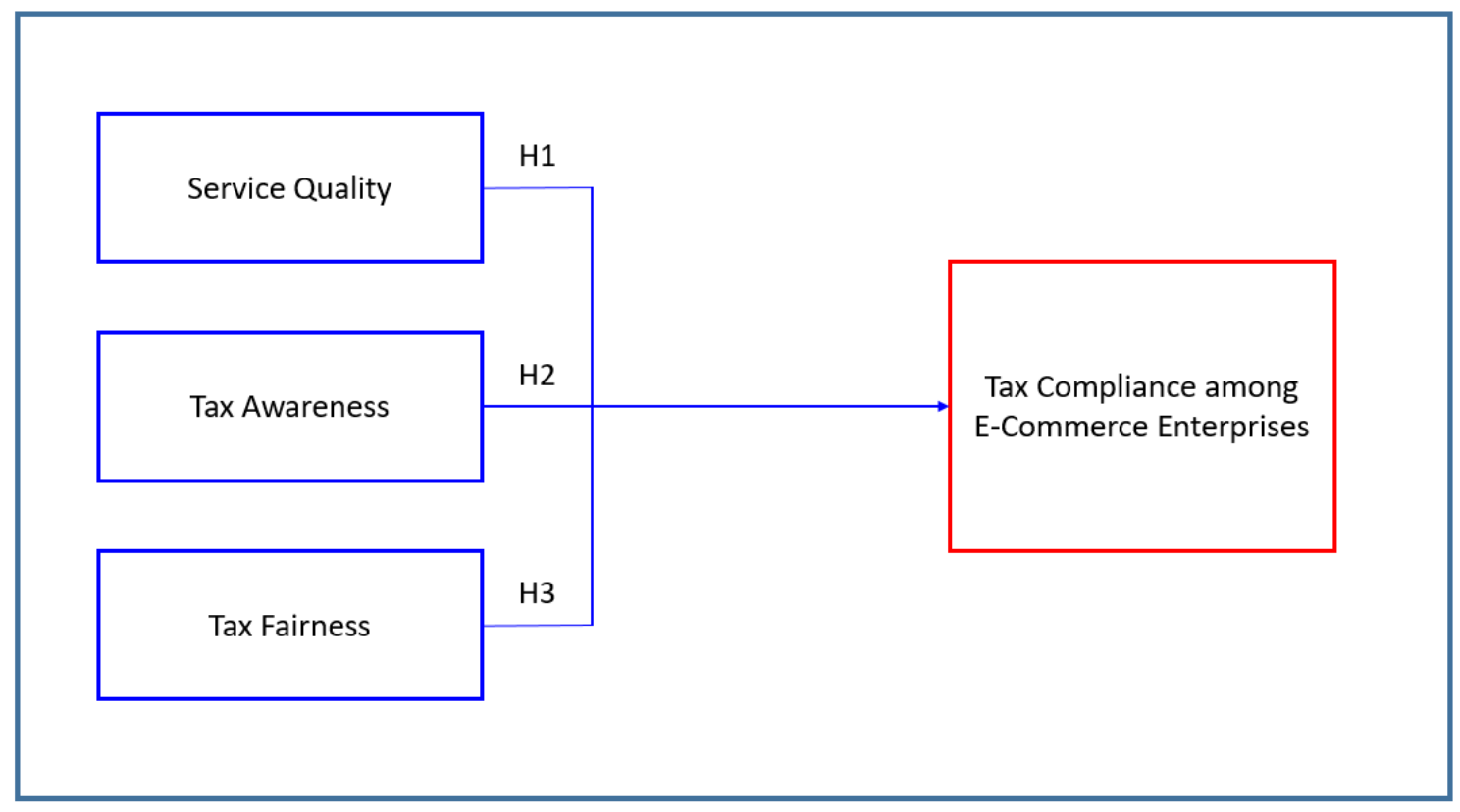

Figure 1. Research Model of Tax Compliance Determinants among E-commerce Enterprise

\section{Conclusions, Implication and Future Research}

This purpose of this paper is to propose on research of determinants influencing e-commerce enterprises taxpayers' compliance in taxation. Review on the relevant past studies indicated that service quality, tax awareness and tax fairness, contribute to tax compliance. This paper has several implication for theory and practice. The theoretical implication of this paper lies in the integration of prior compliance and non-compliance literature in sociology, management and economy as well as physiological to explain determinants in tax compliance. Another theoretical implication is the proposed research model can be used to conduct further research on e-commerce tax and compliance. The practical implication is the information about the determinants of compliance among e-commerce enterprises taxpayer can be utilized by tax authority to take a balance approach to tax enforcement that will encourage voluntary compliance through efficient service quality. This is in turn would maximize tax collection in future. This paper is conceptual discussion, therefore, no empirical 
evidence is provided. Further research could validate and examine the analytical power of the proposed model using mail survey approach. This approach is considered more appropriate compared to other approaches due to issues such as convenience, cost, time and accessibility.

\section{Acknowledgement}

The authors would like to thank the editor of ICSETIA2020 for their valuable time, support, and advice in completing the present research.

\section{Corresponding Author}

Izzie Hadzree Khamis

Azman Hashim International Business School (AHIBS) Universiti Teknologi Malaysia (UTM)

Email: izziehadzree@graduate.utm.my

\section{References List}

\section{Journal Article}

Adhiambo, O. J., \& Theuri, J. M. (2019). Effect of Taxpayer Awareness and Compliance Cost on Tax Compliance Among Small Scale Traders in Nakuru. International Academic Journal of Economics and Finance, 3(3), 279-295.

Akram, H., \& Khan, A. U. (2020). E-commerce trends during COVID-19 Pandemic E-commerce trends during COVID-19 Pandemic. July, 0-4.

Alabede, J. O., Ariffin, Z. Z., \& Idris, K. M. (2011). Individual taxpayers' attitude and compliance behaviour in Nigeria : The moderating role of financial condition and risk preference. Journal of Accounting and Taxation, 3(September), 91-104.

Barrios, A. P. (2010). Factors Influencing Taxpayers' Intention to Adopt Free Electronic Tax Filing. www.igra-world.com

Department of Statistics Malaysia. (2020). Laporan Survei Perbelanjaan Isi Rumah Household Expenditure Survey Report. https://www.dosm.gov.my

Dobson, S., Sukumar, A., Tipi, L., Criminal, E., Davey, M., Mcelwee, G., Smith, R., Mcelwee, G., Smith, R., \& Day, M. J. (2015). Exploring Criminal and Illegal Enterprise : New Perspectives on Research, Policy \& Practice Article information :

Eriksen, K., L. F. (1996). Tax knowledge and attitudes towards taxation; A report on a quasiexperiment. Journal of Business Ethics. http://proquest.umi.com/pqdweb?did=39712230\&Fmt=7\&clientld=25620\&RQT=309\& VName $=P Q D$

Faizal, \& Palil. (2015). Study on Fairness and Individual Tax Compliance in Malaysia: Preliminary Findings. International Journal of Business, Economics and Law, 8(1), 74-79.

Franzoni, L. A. (2000). Tax evasion and tax compliance. Encyclopedia of Law and Economics.

Goetz, M. L. (1978). Tax Avoidance, Horizontal Equity, and Tax Reform: A Proposed Synthesis. Southern Economic Journal, 44(4), 798. https://doi.org/10.2307/1057730

Hamid, N. A., Ibrahim, N. A., Ariffin, N., Taharin, R., \& Jelani, F. A. (2019). Factors Affecting Tax Compliance among Malaysian SMEs in E-Commerce Business. International Journal of Asian Social Science, 9(1), 74-85. https://doi.org/10.18488/journal.1.2019.91.74.85

Hanousek, J., \& Palda, F. (2004). Quality of government services and the civic duty to pay taxes in the Czech and Slovak Republics, and other transition countries. Kyklos, 57(2), 237-252. https://doi.org/10.1111/j.0023-5962.2004.00252.x

Hastuti. (2014). Tax Awareness And Tax Education: A Perception Of Potential Taxpayers. International Journal of Business, Economics and Law, 5(1), 9. 
IRBM. (2013). Guideline on Taxation of Electronic Commerce Transaction (2013) Inland Revenue Board of

Malaysia(IRMB).lampiran1.hasil.gov.my/pdf/pdfam/guidelines_e_commerce_1305201 9.pdf Title.

James, S., \& Alley, C. (2009). Tax Compliance, Self-Assessment and Tax Administration School of Business and Economics, University of Exeter. Journal of Finance and Management in Public Services, 2(2), 27-42.

Kamil, N. I. (2015). The effect of taxpayer awareness, knowledge, tax penalties and tax authorities services on the tax complience: Survey on the individual taxpayer at Jabodetabek \& Bandung). Research Journal of Finance and AccountingOnline), 6(2), 104112. https://www.iiste.org/Journals/index.php/RJFA/article/view/19180/19738

Kirchler, E., Hoelzl, E., \& Wahl, I. (2008). Enforced versus voluntary tax compliance: The "slippery slope" framework. Journal of Economic Psychology, 29(2), 210-225. https://doi.org/10.1016/j.joep.2007.05.004

Kirchler, E., Maciejovsky, B., \& Schneider, F. (2003). Everyday representations of tax avoidance, tax evasion, and tax flight: Do legal differences matter? Journal of Economic Psychology, 24(4), 535-553. https://doi.org/10.1016/S0167-4870(02)00164-2

Liljander, V., Gillberg, F., Gummerus, J., \& Van Riel, A. (2006). Technology readiness and the evaluation and adoption of self-service technologies. Journal of Retailing and Consumer Services, 13(3), 177-191. https://doi.org/10.1016/j.jretconser.2005.08.004

McBarnet, D. (2017). When compliance is not the solution but the problem: From changes in law to changes in attitude. Taxing Democracy: Understanding Tax Avoidance and Evasion, 229-244.

Miazee, M., \& Rahman, M. (2011). E-Service Quality and Customer Satisfaction: A Study of Online Customers in Bangladesh.

Michael, Alm, J., \& Cronshaw, Mckee, M. B. (1993). Tax Compliance with Endogenous Audit Selection Rules. Kyklos, 46(June 1992), 27-46.

Mohammad, A. J. (2019). The Impact of E-Commerce for Taxation. 02(09), 74-91.

Murphy, K. (2009). Procedural justice and affect intensity: Understanding reactions to regulatory authorities. Social Justice Research, 22(1), 1-30. https://doi.org/10.1007/s11211-008-0086-8

Mustapha, B., \& Obid, S. N. B. S. (2015). Tax Service Quality: The Mediating Effect of Perceived Ease of Use of the Online Tax System. Procedia - Social and Behavioral Sciences, 172, 29. https://doi.org/10.1016/j.sbspro.2015.01.328

Natrah. (2012). Perceptions of tax fairness and tax compliance behaviour: A comparative study. Jurnal Pengurusan, 36(2012), 89-100. https://doi.org/10.17576/pengurusan2012-36-08

Negash, S., Ryan, T., \& Igbaria, M. (2003). Quality and effectiveness in Web-based customer support systems. Information and Management, 40(8), 757-768. https://doi.org/10.1016/S0378-7206(02)00101-5

OECD. (2001). Organisation for Economic Co-operation and Development. Compliance Measurement _ Practice Note. Tax Guidance Series, Centre for Tax Policy and Administration.

Ott, K. (1998). Tax Administration Reform in Transition : the Case of Croatia. Financijska Praksa, 2(5), 1-40.

Palil, M. R., \& Rusyidi, M. A. (2013). The Perception of Tax Payers on Tax Knowledge and Tax Education with Level of Tax Compliance: A Study the Influences of Religiosity. ASEAN 
Journal of Economics, Management and Accounting, 1(1), 118-129.

Parasuraman, A., Zeithaml, V. A., \& Berry, L. L. (1985). A Conceptual Model of Service Quality and Its Implications for Future Research. Journal of Marketing, 49(4), 41. https://doi.org/10.2307/1251430

Richardson, G. (2008). The relationship between culture and tax evasion across countries: Additional evidence and extensions. Journal of International Accounting, Auditing and Taxation, 17(2), 67-78. https://doi.org/10.1016/j.intaccaudtax.2008.07.002

Roberts and Hite. (1994). Understanding attitudes towards progressive taxation. Public Opinion Quarterly Volume 58:163-190 O 1994 by the Amcncin Allocation for Public Opinion Research.

Sandmo, A. (2005). The theory of tax evasion: A retrospective view. National Tax Journal, $58(4), 643 \_662$.

Savitri, E., \& Musfialdy. (2016). The Effect of Taxpayer Awareness, Tax Socialization, Tax Penalties, Compliance Cost at Taxpayer Compliance with Service Quality as Mediating Variable. Procedia - Social and Behavioral Sciences, 219, 682-687. https://doi.org/10.1016/j.sbspro.2016.05.051

Setyonugroho, H., \& Sardjono, B. (2012). Factors Affecting Willingness To Pay Taxes on Individual Taxpayers At Pratama Surabaya Tegalsari Tax Office. The Indonesian Accounting Review, 3(01), 77. https://doi.org/10.14414/tiar.v3i01.214

Siahaan, F. (2005). The Influence Of Tax Fairness, Ethical Attitudes And Commitment On Taxpayer Compliance Behavior. The International Journal of Accounting and Business Society, 13(1), 33-44.

Singh, V. (2005). Tax thoughts on today's taxing times. (1st edition). Kuala Lumpur: Digibook Sdn Bhd.

Smith, A. (1976). An inquiry into the nature and causes of the wealth of the nation. In Oxford University

Press.

https://ejournal.poltektegal.ac.id/index.php/siklus/article/view/298\%0Ahttp://reposit orio.unan.edu.ni/2986/1/5624.pdf\%0Ahttp://dx.doi.org/10.1016/j.jana.2015.10.005\%0 Ahttp://www.biomedcentral.com/1471-

2458/12/58\%0Ahttp://ovidsp.ovid.com/ovidweb.cgi?T=JS\&P

Stiglingh, M. (2014). Service quality framework for the South African Revenue Service from the perspective of the tax practitioner. Public Relations Review, 40(2), 240-250. https://doi.org/10.1016/j.pubrev.2013.11.014

Thornton, J. M., \& Shaub, M. K. (2014). Tax services, consequence severity, and jurors' assessment of auditor liability. Managerial Auditing Journal, 29(1), 50-75. https://doi.org/10.1108/MAJ-03-2013-0834

Torgler, B. (2013). Tax Compliance and Tax Morale. Tax Compliance and Tax Morale. https://doi.org/10.4337/9781847207203

Turban, E., Outland, J., King, D., Lee, J. K., Liang, T.-P., \& Turban, D. C. (2018). Electronic Commerce 2018. https://doi.org/10.1007/978-3-319-58715-8

Tyler, T. R., \& Lind, E. A. (1992). A relational model of authority in groups. Advances in Experimental Social Psychology, 25(C), 115-191. https://doi.org/10.1016/S00652601(08)60283-X

Wenzel, M. (2002). Tax compliance and the psychology of justice: mapping the field. In Taxing Democracy. http://www.ashgate.com/isbn/9780754622437

Westberg, B. (2002). Cross-Border Taxation of. IBFD.

Yapar, B. K., Bayrakdar, S., \& Yapar, M. (2015). The Role of Taxation Problems on the 
Development of E-Commerce. Procedia - Social and Behavioral Sciences. https://doi.org/10.1016/j.sbspro.2015.06.145

Yayuk, N. R., Margono, S., Eka, A. T., \& Sudjatno. (2017). The role of taxpayer awareness, tax regulation and understanding in taxpayer compliance. Journal of Accounting and Taxation, 9(10), 139-146. https://doi.org/10.5897/jat2017.0267

Yee, P., Moorthy, C., K., \& Soon, C. K. W. (2017). Taxpayers' perceptions on tax evasion behaviour: an empirical study in Malaysia. International Journal of Law and Management, 59(3), 413-429. https://doi.org/10.1108/IJLMA-02-2016-0022

Youde, S., \& Lim, S. (2019). The Determinants of Medium Taxpayers' Compliance Perspectives: Empirical Evidence from Siem Reap Province, Cambodia. International Journal of Public Administration, 42(14), 1222-1233. https://doi.org/10.1080/01900692.2019.1591447

\section{Online Newspaper Articles}

Aziz, A. (2019). IRB set to tighten enforcement on shadow economy next year. The Malaysian Reserve. Retrieved from https://themalaysianreserve.com/2019/11/07/irb-set-totighten-enforcement-on-shadow-economy-next-year/

Ching, O. T. (2019). A shadow economy 'a serious concern'. New Straits Times. Retrieved from https://www.pressreader.com/malaysia/new-straitstimes/20191016/281633897002767

Guie, L. H. (2020). The RM300 bil shadow economy. The Star. Retrieved from https://www.thestar.com.my/business/business-news/2020/02/29/the-rm300bilshadow-economy

Malaysian Investment Development Authority (MIDA). (2020). A bountiful year of ecommerce. Retrieved from https://www.mida.gov.my/home/9767/news/a-bountifulyear-for-e-commerce-/

\section{Technical and Research Reports}

eCommerce worldwide. Retrieved from

https://www.statista.com/outlook/243/100/ecommerce/worldwide 